\title{
Assessment of Genetic Diversity in Tomato (Solanum lycopersicum) Under Protected Condition
}

\author{
T. P. Kiran ${ }^{1 *}$, V. Srinivasa ${ }^{1}$, Devaraju ${ }^{1}$, B. M. Dushyanth ${ }^{2}$, \\ M. Ganapathi ${ }^{3}$ and A. Akshay ${ }^{1}$
}

${ }^{1}$ Department of Vegetable Science, ${ }^{3}$ Department of Crop Physiology, College of Horticulture, Mudigere, Karnataka, India

${ }^{2}$ Department of Genetics and Plant Breeding, College of Agriculture, Shivamogga, Karnataka, India

*Corresponding author

\section{A B S T R A C T}

\begin{tabular}{|l|}
\hline Ke y w o r d s \\
Genetic \\
$\begin{array}{l}\text { Divergence, Cluster } \\
\text { Analysis, } \mathrm{D}^{2}, \\
\text { Tomato }\end{array}$ \\
\hline Article Info \\
\hline $\begin{array}{l}\text { Accepted: } \\
10 \text { September } 2020 \\
\text { Available Online: } \\
10 \text { October } 2020\end{array}$ \\
\hline \hline
\end{tabular}

In the present study, 22 tomato (Solanum lycopersicum L.) genotypes were evaluated to study the extent of genetic diversity through 20 quantitative traits. The genotypes were categorized into 5 distinct clusters using $\mathrm{D}^{2}$ statistics. Cluster I had the maximum number of genotypes (8), followed by clusters IV and V (4 genotypes each) and clusters II and III (3 genotypes each). Highest intra cluster was recorded in cluster III, while the inter cluster distance was maximum between cluster V and cluster IV $(53,348.13)$ indicating the presence of wide range of variability among genotypes of the cluster. Fruit yield per plant contributed the maximum $(64.50 \%)$ to the genetic diversity, followed by fruit volume, number of fruits per plant, average fruit weight, number of locules per fruit, fruit diameter and fruit length. The cluster III recorded highest mean for the characters like fruit length $(4.28 \mathrm{~cm})$, fruit diameter $(5.12 \mathrm{~cm})$, fruit volume $(115.58 \mathrm{cc})$, average fruit weight $(114.20$ $\mathrm{g})$, pericarp thickness $(6.70 \mathrm{~mm})$ and fruit yield per plant $(1.64 \mathrm{~kg})$.

\section{Introduction}

Tomato (Solanum lycopersicum L.) is an important vegetable of solanaceae family having diploid chromosome number of $2 n=2 x=24$. It has originated in Peru- EquadorBolivia region of the Andes, South America (Rick, 1969). It is commonly considered as "Protective Food", as it contains high amount of several nutritive phytochemical compounds especially carotenoids such as, lycopene and $\beta$-carotene (provitamin A), flavonoids, phenolic acids, ascorbic acid and minerals like calcium, iron and phosphorus. In India, tomato ranks second among vegetables in area and production after potato. It occupies in an area of 1.20 million hectares with an annual production of 19.40 million tonnes with an average yield of 16.16 tonnes per hectare. By realizing remuneration of tomato under protected cultivation there is a perpetual need for crop improvement in indeterminate types of tomato regarding longer harvest duration, fruit yield and fruit 
quality. Genetic improvement can be done by designing the genetic makeup of the plant with desirable characters and by eliminating the undesirable genes.

The scope of crop improvement depends upon the genetic diversity of the initial plant material. The progenies derived from diverse parents are expected to display a broad spectrum of genetic variability and greater heterosis which provides better scope to isolate superior recombinants (Lahbib et al., 2010; Srivastava et al., 2014). Characterization of genetic divergence for selection of suitable and diverse genotypes should be based on sound statistical procedures. The generalized $\mathrm{D}^{2}$ statistic, revised by Mahalanobis (1936), is a powerful technique to identify diverse groups in any material. Further, grouping of the accessions based on Tocher's method will be more useful in choosing suitable parents for heterosis breeding (Prashanth et al., 2008). Keeping these points, present investigation was taken up to study the genetic divergence among the selected tomato germplasm.

\section{Materials and Methods}

The experimental material comprising of twenty-two genotypes of tomato which includes both semi determinate and indeterminate types and these were collected from institutes like IIHR Bengaluru, IIVR Varanasi, NBPGR New Delhi and IARI Delhi. Evaluation of these accessions was carried out to estimate the variability and for grouping them into different clusters using $\mathrm{D}^{2}$ statistics of Mahalanobis. The genotypes were evaluated in randomized block design with two replications during Rabi, 2019-20 at Department of Vegetable Science, College of Horticulture Mudigere, University of Agricultural and Horticultural Sciences, Shivamogga, India. The twenty-five days old seedlings of selected genotypes were transplanted in the experimental field with the spacing $60 \mathrm{~cm} \times 45 \mathrm{~cm}$, in a such a way that to accommodate twelve plants in each plot $\left(3.5 \mathrm{~m}^{2}\right)$. The recommended package of practices was followed for raising all the genotypes. Necessary prophylactic plant protection measures were taken up to safe guard the genotypes from pests and diseases.

Twenty quantitative characters viz., plant height at last harvest $(\mathrm{cm})$, stem girth at last harvest $(\mathrm{cm})$, number of primary branches per plant at last harvest, number of secondary branches per plant at last harvest, days taken for first flowering, days taken for fifty per cent flowering, number of flowers per cluster, number of fruits per cluster, number of fruit clusters per plant, days taken for fruit set, days taken for fruit harvest, days taken from first harvest to last harvest, number of fruits per plant, fruit length $(\mathrm{cm})$, fruit diameter $(\mathrm{cm})$, fruit volume $(\mathrm{cc})$, average fruit weight $(\mathrm{g})$, pericarp thickness $(\mathrm{mm})$, number of locules per fruit and fruit yield per plant $(\mathrm{kg})$ were taken into consideration for estimating genetic diversity. The mean values of five plants were taken for the analysis of genetic divergence following Mahalanobis (1936). The genotypes were grouped into different clusters following Tocher's method as described by Rao (1952). The average intra and inter cluster distances and contribution of characters towards genetic divergence were estimated by using the method as described by Singh and Chaudhary (1985).

\section{Results and Discussion}

On the basis of $\mathrm{D}^{2}$ analysis, twenty-two genotypes were grouped into five clusters (Table 1). Maximum number of genotypes were grouped into cluster I (8 genotypes) followed by cluster IV and V (4 genotypes each), cluster II and III (3 genotypes each). The results of the present study revealed that clustering was not allied with geographic 
origin because some genotypes collected from the same geographic origin were grouped in different clusters. The findings of the present investigation are supported by the findings of Chernet et al., (2013), Hussain et al., (2018), Raj et al., (2019). Thus, there is no direct relationship between geographical distribution and genetic distance.

Intra and inter cluster average $\mathrm{D}^{2}$ values are presented in Table 2. Among the five clusters, cluster III with 3 genotypes showed the maximum intra cluster distance (4540.01) followed by cluster V (4434.02) and cluster II (3836.99), cluster I (2653.48) and cluster IV (2572.86). Based on distances between clusters, i.e., inter cluster distances, the maximum divergence was observed between cluster V and IV $(53,348.13)$, followed by cluster IV and III (42,314), cluster V and II $(31,707.76)$, cluster $\mathrm{V}$ and I $(28,411.42)$, cluster III and I (26,222.69), cluster II and III $(19,933.32)$, cluster V and III (11,911.94), cluster IV and I (9,960.24), cluster II and IV $(8,012.84)$ and cluster II and I had least inter cluster distance $(6,825.89)$. In accordance to the findings, Hazra et al., (2010) and Meena and Bahadur (2015) reported that the maximum inter cluster D2 values revealed that these can be utilized for getting superior recombinants or transgressive segregants as they represent very diverse group of genotypes.

The relative contribution of different characters for genetic divergence $\left(\mathrm{D}^{2}\right)$ is given in Figure 1. Fruit yield per plant contributed the maximum $(64.50 \%)$ to the genetic diversity among the characters followed by fruit volume (19.91\%), number of fruits per plant $(6.49 \%)$, average fruit weight $(4.33 \%)$, number of locules per fruit $(3.03 \%)$, fruit diameter and fruit length $(0.87$ $\%$ each). Similar to the present findings was recorded by Babu et al., (2018), Naveen et al., (2018) and Prakash et al., (2019).

Table.1 Cluster composition based on $\mathrm{D}^{2}$ statistics in tomato genotypes

\begin{tabular}{|c|c|c|}
\hline Clusters & Number of genotypes & Genotypes included in the cluster \\
\hline I & 8 & $\begin{array}{l}\text { Kashi Vishesh, EC 521039, Kashi Eyan, EC } 13736 \text {, } \\
\text { Arka Alok, Arka Sourabh, Pusa Ruby, VRT } 51\end{array}$ \\
\hline II & 3 & EC 531804, IIHR 2615, VRT 13 \\
\hline III & 3 & EC 362941, Marglobe, Arka Megali \\
\hline IV & 4 & EC 27251, ToLEV 32, EC 521076, VRT 06 \\
\hline $\mathbf{V}$ & 4 & EC 15127, EC 521061, EC 521069, Arka Vikas \\
\hline
\end{tabular}

Table.2 Average intra and inter clusters $\mathrm{D}^{2}$ values for twenty characters formed by twenty- two genotypes of tomato

\begin{tabular}{|l|c|c|c|c|c|}
\hline & Cluster 1 & Cluster 2 & Cluster 3 & Cluster 4 & Cluster 5 \\
\hline Cluster 1 & $\mathbf{2 6 5 3 . 4 8}$ & 6825.89 & 26222.69 & 9960.24 & 28411.42 \\
\hline Cluster 2 & & $\mathbf{3 8 3 6 . 9 9}$ & 19933.32 & 8012.84 & 31707.76 \\
\hline Cluster 3 & & & $\mathbf{4 5 4 0 . 0 1}$ & 42314 & 11911.94 \\
\hline Cluster 4 & & & & $\mathbf{2 5 7 2 . 8 6}$ & 53348.13 \\
\hline Cluster 5 & & & & & $\mathbf{4 4 3 4 . 0 2}$ \\
\hline
\end{tabular}


Table.3 Mean values of twenty characters for five clusters in tomato genotypes

\begin{tabular}{|c|c|c|c|c|c|c|}
\hline \multirow{2}{*}{$\begin{array}{l}\text { Sl. } \\
\text { No. }\end{array}$} & \multirow[t]{2}{*}{ Characters } & \multicolumn{5}{|c|}{ Clusters } \\
\hline & & I & II & III & IV & $\mathbf{V}$ \\
\hline 1 & Plant height $(\mathrm{cm})$ at last harvest & 237.75 & 203.39 & 230.63 & 215.81 & 312.03 \\
\hline 2 & Stem girth $(\mathrm{cm})$ at last harvest & 4.32 & 4.50 & 4.77 & 5.53 & 4.27 \\
\hline 3 & $\begin{array}{l}\text { Number of primary branches per } \\
\text { plant at last harvest }\end{array}$ & 7.97 & 8.93 & 8.05 & 8.21 & 9.02 \\
\hline 4 & $\begin{array}{l}\text { Number of secondary branches } \\
\text { per plant at last harvest }\end{array}$ & 20.55 & 26.39 & 22.43 & 20.86 & 26.21 \\
\hline 5 & Days taken for first flowering & 25.46 & 26.72 & 25.25 & 25.10 & 24.28 \\
\hline 6 & Days taken for per cent flowering & 29.14 & 30.53 & 28.90 & 29.29 & 29.37 \\
\hline 7 & Number of flowers per cluster & 5.25 & 6.64 & 4.93 & 6.79 & 5.22 \\
\hline 8 & Number of fruits per cluster & 5.07 & 5.29 & 4.87 & 5.57 & 3.99 \\
\hline 9 & Number of fruit clusters per plant & 31.17 & 28.33 & 23.13 & 35.87 & 29.16 \\
\hline 10 & Days taken for fruit set & 8.93 & 7.55 & 8.22 & 8.37 & 8.28 \\
\hline 11 & Days taken for first harvest & 64.16 & 64.74 & 55.86 & 56.23 & 62.16 \\
\hline 12 & $\begin{array}{l}\text { Days taken from first harvest to } \\
\text { last harvest }\end{array}$ & 39.37 & 42.99 & 47.97 & 45.31 & 49.59 \\
\hline 13 & Number of fruits per plant & 34.59 & 33.03 & 19.66 & 44.47 & 29.54 \\
\hline 14 & Fruit length $(\mathrm{cm})$ & 2.91 & 3.59 & 4.28 & 3.42 & 3.41 \\
\hline 15 & Fruit diameter $(\mathrm{cm})$ & 3.12 & 4.53 & 5.12 & 3.68 & 3.46 \\
\hline 16 & Fruit volume (cc) & 32.10 & 73.15 & 115.58 & 36.28 & 47.25 \\
\hline 17 & Average fruit weight (g) & 35.79 & 83.31 & 114.42 & 47.79 & 50.4 \\
\hline 18 & Pericarp thickness (mm) & 4.37 & 5.22 & 6.70 & 4.54 & 4.74 \\
\hline 19 & Number of locules per fruit & 3.24 & 3.88 & 4.78 & 2.76 & 3.09 \\
\hline 20 & Fruit yield per plant (kg/plant) & 1.27 & 1.70 & 1.64 & 1.62 & 1.25 \\
\hline
\end{tabular}

Fig.1 Per cent contribution from different characters to the total divergence in tomato genotypes

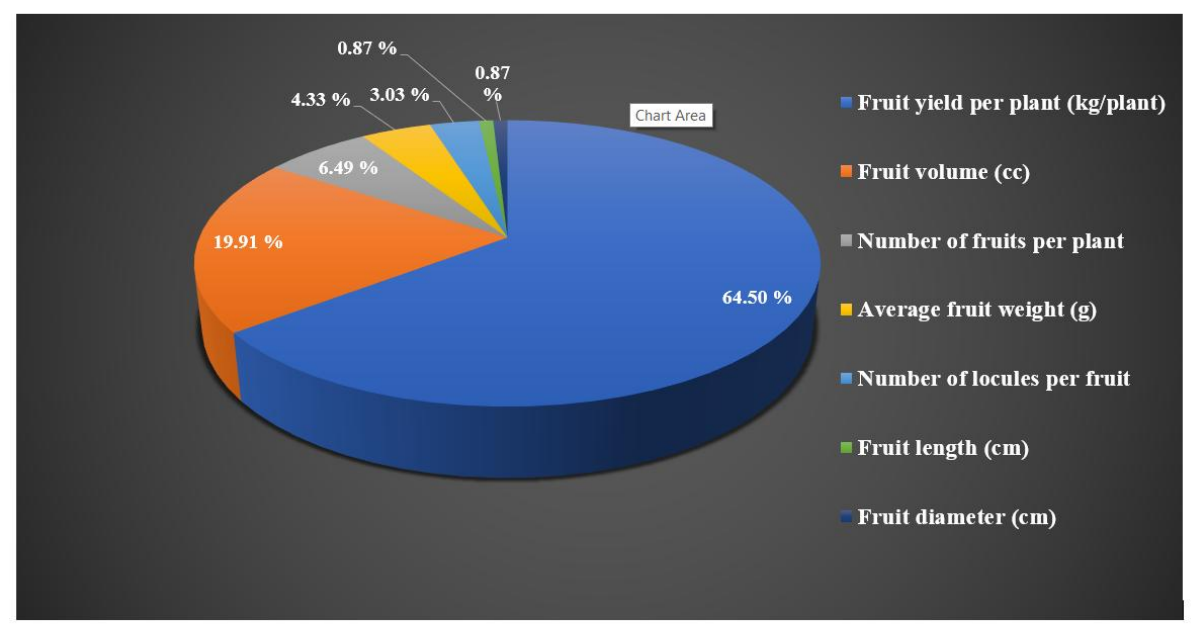


The cluster means for 20 characters indicated, considerable difference among clusters for all the characters (Table 3). The Cluster II recorded highest mean for the characters like number of secondary branches per plant at last harvest (26.39), whereas the cluster III recorded highest mean for the characters like fruit length $(4.28 \mathrm{~cm})$, fruit diameter $(5.12$ $\mathrm{cm})$, fruit volume $(115.58 \mathrm{cc})$, average fruit weight $(114.20 \mathrm{~g})$, pericarp thickness $(6.70$ $\mathrm{mm})$ and fruit yield per plant $(1.64 \mathrm{~kg})$. The cluster IV recorded highest mean for the characters like stem girth at last harvest (5.53 $\mathrm{cm}$ ), number of flowers per cluster (6.79), number of fruits per cluster (5.57), number of fruit clusters per plant (35.87) and number of fruits per plant (44.47). The cluster V recorded highest mean for the characters like plant height at last harvest $(312.03 \mathrm{~cm})$, number of primary branches per plant at last harvest (9.02) and days taken from first harvest to last harvest (49.59). Hence, crosses between these clusters may improve respective selected traits.

\section{References}

Babu, M.R., Reddy, R.V.K., Reddy, K.R., Saidaiah, P. and Rani, A.S. 2018. Studies on genetic diversity in tomato (Solanum lycopersicum L.). Journal of pharmacognosy and phytochemistry. SP 1: 13-17.

Chernet, S., Belew, D. and Abay, F. 2013. Variability and association of characters in tomato (Solanum lycopersicum L.) genotypes in Northern Ethopia. International Journal of Agricultural Research. 3: 110.

Hazra, P., Sahu, P.K., Roy, U., Dutta, R., Roy, T. and Chattopadhyay, A. 2010. Heterosis in relation to multivariate genetic divergence in brinjal (Solanum melongena). Indian Journal of Agricultural Science. 80:119-124.
Hussain. I., Akhan. S., Ali, S., Farid, A., Ali, N., Ali, S., Masaud, S., Hussain, I., Azeem, K. and Raza, H. 2018. Genetic diversity among tomato accessions based on agro-morphological traits. Sains Malaysiana. 47(11): 2637-2645.

Lahbib, K., Bnejdi, F. and Gazzah, E. I., 2010, Genetic diversity evaluation of pepper Tunisia based on morphologic characters. African journal of agricultural research. 7(23): 34133417.

Mahalanobis, P.C. (1936). On the generalized distance in statistics. Proceedings of National. Academy Sureja and Science. 19: 201-208.

Meena, O.P and Bahadur, V. 2015. Breeding potential of indeterminate tomato (Solanum lycopersicum L.) accessions using $\mathrm{D}^{2}$ analysis. SABRAO Journal of Plant Breeding and Genetics. 47(1):49-59.

Naveen, B.L., Reddy, R.K. and Saidaiah. P. 2018. Genetic divergence for yield and yield attributes in tomato (Solanum lycopersicum). Journal of Agricultural Research. 88(7): 10181023.

Prakash, O., Choudhary, S., Kumar, S. and Godara, A. 2019. Genetic divergence studies in tomato (Solanum $\begin{array}{lll}\text { lycopersicum } & \text { L.). Journal of }\end{array}$ pharmacognosy and phytochemistry. 8(3): 4486-4488.

Prashanth, S.J., Jaiprakashnarayan, R.P., Mulge, R., and Madalageri, M.B. 2008. Genetic divergence in tomato (Lycopersicon esculentum Mill.). The Asian Journal of Horticulture. 3(2): 290-292.

Raj, N., Mukesh, S. M., Singh, D.B., Anand, J. S. and Arun, K. 2019. Genetic divergence in tomato (Solanum lycopersicum L.) based on morphochemical traits under polyhouse in Uttarakhand. International Journal of 
Biological Sciences. 8(2): 80-84.

Rao, C.R. 1952. Advanced statistical methods in biometrics research. John Wiley and Sons, New York. p. 357-369.

Singh, R.K. and Chaudhary, B.D. 1985. Biometrical method in quantitative genetics analysis, Kalyani publishers, New Delhi.
Srivastava, M.K., Agarwal, V.K. and Agarwal, R.K. 2014. Estimation of genetic divergence among indigenous and exotic accessions of tomato (Solanum lycopersicum L.). Asian Journal Bioscience. 9(1): 30-34.

\section{How to cite this article:}

Kiran, T. P., V. Srinivasa, Devaraju, B. M. Dushyanth, M. Ganapathi and Akshay, A. 2020. Assessment of Genetic Diversity in Tomato (Solanum lycopersicum) Under Protected Condition. Int.J.Curr.Microbiol.App.Sci. 9(10): 937-942. doi: https://doi.org/10.20546/ijcmas.2020.910.112 